\title{
VATS Sympathectomy for Refractory Ventricular Arrhythmias: Is It Helpful?
}

\author{
Natalie N Merchant $\mathrm{BS}^{1}$ and Osita Onugha $\mathrm{MD}, \mathrm{MBA}^{2 *}$ \\ ${ }^{1}$ David Geffen School of Medicine at UCLA, USA
}

${ }^{2} J o h n$ Wayne Cancer Institute, USA

Submission: November 23, 2017; Published: December 19, 2017

*Corresponding author: Osita Onugha MD, MBA, John Wayne Cancer Institute, 2121 Santa Monica Blvd, Cardiothoracic Outpatient Clinic, Santa Monica, CA 90404, USA, Tel: (310) 829-8618; Fax: (310) 829-8607; Email: osita.onugha@providence.org

\begin{abstract}
The sympathetic nervous system is a key component of the generation of many life-threatening ventricular arrhythmias [1]. Various medical therapies target the sympathetic nervous system, with the goal of diminishing ventricular arrhythmias, ultimately for the protection of the structural and functional integrity of cardiac tissue. Ventricular arrhythmias that are refractory to medical management can contribute to degeneration of cardiomyocyte and can lead to the development of heart failure and increase the risk of sudden cardiac death. This article will review the relevant literature surrounding medical and surgical management of refractory ventricular arrhythmia, and determine if there is evidence to support the recommendation of bilateral upper thoracic sympathectomy as a beneficial option for management.
\end{abstract}

Keywords: Ventricular arrhythmia; Thoracic sympathectomy; Stellate ganglia; Sudden cardiac death

\section{Introduction}

Theautonomicnervoussystemhasacriticalroleintheregulation and coordination of cardiac electrophysiology. The sympathetic nervous system contributes to both physiology of cardiomyocyte excitation and pathophysiology of ventricular arrhythmias. In normal physiology, the pre-ganglionic sympathetic efferent fibers originate at the T1-T4 spinal cord. The fibers travel through the stellate ganglia within the paravertebral sympathetic chain

to send post-ganglionic efferent fibers to innervate the heart for modification of heart rate and blood pressure as a mechanism to maintain homeostasis and react in response to stimuli (Figure 1) $[2,3]$. However, in cardiac pathophysiology, the sympathetic nervous system has a major role in the production of ventricular tachyarrhythmia (VT) and ventricular fibrillation (VF) via the innervation from the right and left stellate ganglia to the anterior left ventricle [4-6].

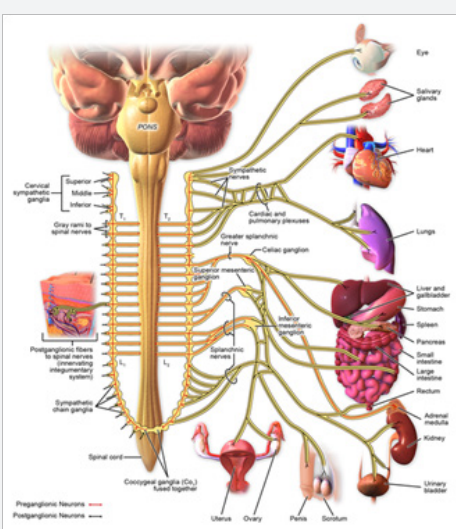

Sympathetic Innervation

Figure 1: Rendering of pre- and post- ganglionic sympathetic nerve fibers to various organs [2]. 


\section{Review of the Literature}

\section{Treatment of ventricular arrhythmiass}

Patients with symptomatic non-sustained VT (NSVT) are treated initially with beta blockers, as these medications are also indicated for co-existing cardiac conditions (eg: heart failure). Despite reducing arrhythmia frequency, many patients are either intolerant or refractory to beta blockers and remain at risk of sudden death $[5,6]$. If patients are medically refractory to beta blockers, the addition of nondihydropyridine calcium channel blockers (ie., verapamil and diltiazem) can be added as medical therapy, instead of adding a Class I or III antiarrhythmic, unless the patient has uncontrolled heart failure. Cardiac catheter ablation is indicated for patients who have frequent NSVT that is either uncontrolled on medication or patients unwilling to take medication [7]. Implantable cardiovert-defibrillators (ICD) are indicated for primary prevention of sudden cardiac death (SCD) in patients who have NSVT with underlying cardiomyopathy [8]. In the AVID trial, the ICD improved overall survival compared with antiarrhythmic medication therapy (primarily amiodarone) with a 2-year relative risk reduction in mortality of $27 \%$ and an absolute risk reduction of 7\% [9]. An ICD can effectively protect against lethal arrhythmias, but they can cause inappropriate shocks which can rearrange underlying cardiomyoctye and still leave patients at risk for sudden cardiac death $[4,6,10]$.

\section{Indications for sympathectomy}

Patients who are unresponsive to pharmacologic, cardiac ablation or ICD therapies for VA, the modulation of the cardiac autonomic nervous system can be an effective and life-saving solution as the VAs can progress to sudden cardiac death $[3,5,6,11]$. Using a thoracoscopic approach with $\mathrm{CO}_{2}$ insufflation, the sympathetic chain is identified under the ipsilateral pleura. Several authors report transecting or removing the nerve starting from the lower one-half to one-third of the stellate ganglion down to just above R4 ( $4^{\text {th }}$ rib) in order to target the T1-T4 fibers which are innervating the left ventricle $[4,6]$. Rib-oriented nomenclature ( $\mathrm{R}$ referring to rib, and the number referring to which rib) is used to determine the location where the sympathetic chain is interrupted [12]. We typically divide the lower one-third of the stellate ganglion to reduce the risk of Horner syndrome. After resection of the sympathetic nerve, histological analysis is typically performed for confirmation of neuronal cell bodies within the ganglia. Chest tubes are placed at the end of the procedure and removed on post-operative day (POD) 1 if there is no evidence of a hemothorax.

Table 1: Summary of the post-operative results for left or bilateral sympathectomy.

\begin{tabular}{|c|c|c|c|}
\hline $\begin{array}{c}\text { Author, Year [Ref], Journal, (No. } \\
\text { of Patients) }\end{array}$ & Laterality of Surgery & Success Rate & Patient Population \\
\hline $\begin{array}{l}\text { Vaseghi [14], Journal of the } \\
\text { American College of Cardiology, } \\
\qquad n=121\end{array}$ & Left or Bilateral & $\begin{array}{l}\text { CSD* reduced the burden of ICD } \\
\text { shocks }(p<0.01)\end{array}$ & $\begin{array}{l}\text { Patients with structural heart } \\
\text { disease with recurrent VT or VT } \\
\text { storm }\end{array}$ \\
\hline $\begin{array}{c}\text { Schwartz [11], Nature Reviews } \\
\text { Cardiology, n=N/A }\end{array}$ & Left & $\begin{array}{l}\text { Definitive evidence now shows } \\
\text { that LCSD* has powerful } \\
\text { antiarrhythmic and antifibrillatory } \\
\text { effects }\end{array}$ & $\begin{array}{l}\text { Patients with channelopathies, } \\
\text { such as LQTS and CPVT }\end{array}$ \\
\hline $\begin{array}{l}\text { Ajijola [12], Journal of the } \\
\text { American College of Cardiology, } \\
n=6\end{array}$ & Bilateral & $\begin{array}{c}\text { After BCSD*, complete response } \\
\text { was observed in } 66.7 \% \text { of patients } \\
(4 \text { of } 6)\end{array}$ & $\begin{array}{l}\text { Patients with incessantventricular } \\
\text { tachycardia (VT) or repeated } \\
\text { episodes of ventricular fibrillation }\end{array}$ \\
\hline $\begin{array}{l}\text { Coleman [5], } \\
\text { CircArrhythmElectrophysiol, } \mathrm{n}=91\end{array}$ & Left & $\begin{array}{l}76 \% \text { of patients to be event free } \\
\text { post procedure }\end{array}$ & $\begin{array}{l}\text { Patients with non- } \\
\text { long-QT syndrome, } \\
\text { arrhythmogenicchannelopathies } \\
\text { and cardiomyopathies }\end{array}$ \\
\hline Vaseghi [3], Heart Rhythm, n=41 & $\begin{array}{l}\text { Left or Bilateral (14 and 27, } \\
\text { respectively) }\end{array}$ & $\begin{array}{l}\text { Bilateral CSD group had a greater } \\
\text { survival from ICD shocks at follow- } \\
\text { up }\end{array}$ & Porcine subjects \\
\hline
\end{tabular}

*Key: CSD: Cardiac Sympathetic Denervation; LCSD: Left Cardiac Sympathetic Denervation;

BCSD: Bilateral Cardiac Sympathetic Denervation; ICD: Implantable Cardiovert-Defibrillator

\section{Results}

There is evidence that removal of either left or bilateral thoracic (stellate and upper thoracic) sympathetic ganglia for the management of ventricular arrhythmia (VT/VF) is effective. See Table 1. A literature review by Schwartz advocates for left-only denervation as left sided sympathetic nerves are dominant in the left ventricle. However, Ajijola et al. [13] suggest left cardiac sympathetic denervation (LCSD) is ineffective in suppressing
VAs, and advocate for bilateral cardiac sympathetic denervation (BCSD) [14].

Other techniques for cardiac neuromodulation for patients with refractory VAs are spinal cord stimulation, thoracic epidural anesthesia, and renal denervation. These methods can be used as treatment options for both atrial and ventricular arrhythmias $[11,15]$. 


\section{Discussion}

The first studies of sympathectomy for arrhythmia by Estes and Zipes et al. $[16,17]$ were focused primarily on ventricular tachycardia and were successful in preventing recurrent arrhythmia. Numerous literature reviews, retrospective analyses, and case reports since then have demonstrated that bilateral sympathectomy with stellate ganglionectomy allows for the disruption of the autonomic cardiac nervous system which decreases ICD shock and sudden cardiac death in patients with VT/VF refractory to medical management and cardiac ablation.

The two most frequently published complications of sympathectomy are Horner syndrome and compensatory hyperhidrosis. Division of the fibers transversing the upper stellate ganglia and sparing the cranial aspects of the nerve minimizes the occurrence of Horner syndrome [3,13]. Our experience with bilateral sympathectomy has revealed several techniques that can be incorporated into current surgical practice. We've found that avoidance of electrocautery for the dissection of the sympathetic nerve near the stellate ganglia fibers decreases the likelihood of Horner syndrome. The current produced by electrocautery transmits beyond the stellate ganglia thereby injuring the cranial aspects of the nerve and causing the sympathetically driven ptosis, miosis and anhidrosis of the ipsilateral face. Instead of electrocautery for the stellate division, we recommend using microscissors for blunt dissection and dividing the nerve fibers.

Compensatory hyperhidrosis presents immediately after surgery and can be classified into mild, moderate, or intense. Intense compensatory hyperhidrosis is defined as the sweating which occurs in large quantities with little stimuli and requires change of clothes more than once a day [18]. Studies demonstrate that sympathectomy above the R2 (second rib) increases the risk of severe compensatory hyperhidrosis $[18,19]$. Although we have not seen it in our practice, the risk of severe compensatory hyperhidrosis must be explained and discussed with all patients.

Since many of these patients are on anti-platelet therapy or anticoagulation for underlying coronary artery disease, cardiomyopathy, or arrhythmia, we've also found that introduction of hemostatic agents intra-operatively has prevented the rare return to the operating room for evacuation of hemothorax.

\section{Conclusion}

Several articles spanning various medical specialties discuss the significant decrease in ICD shock, SCD, and increases in survival post-sympathectomy. This review of relevant literature suggests that bilateral VATS sympathectomy of the lower half of the left stellate ganglion (T1) and thoracic ganglia T2 to T4, is a therapeutic option for ventricular arrhythmias that are refractory to beta blockade, cardiac ablation and/or ICD for the prevention of lethal arrhythmias and sudden cardiac death.

\section{References}

1. Hofferberth SC, Cecchin F, Loberman D, Fynn-thompson F (2014) Left thoracoscopic sympathectomy for cardiac denervation in patients with life-threatening ventricular arrhythmias. J Thorac Cardiovasc Surg 147(1): 404-409.

2. Blausen.com staff (2014) Medical gallery of blausen medical 2014 . Wiki Journal of Medicine 1(2). DOI:10.15347/wjm/2014.010.

3. Buckley U, Yamakawa K, Takamiya T, Andrew armour J, Shivkumar $\mathrm{K}$, et al. (2016) Targeted stellate decentralization: Implications for sympathetic control of ventricular electrophysiology. Heart Rhythm 13(1): 282-288.

4. Vaseghi M, Gima J, Kanaan C, Ajijola OA, Marmureanu A, et al. (2014) Cardiac sympathetic denervation in patients with refractory ventricular arrhythmias or electrical storm: intermediate and longterm follow-up. Heart Rhythm 11(3): 360-366.

5. Vaseghi M, Zhou W, Shi J, Ajijola OA, Hadaya J, et al. (2012) Sympathetic innervation of the anterior left ventricular wall by the right and left stellate ganglia. Heart Rhythm 9(8): 1303-1309.

6. Coleman MA, Bos JM, Johnson JN, Owen HJ, Deschamps C, et al. (2012) Videoscopic left cardiac sympathetic denervation for patients with recurrent ventricular fibrillation/malignant ventricular arrhythmia syndromes besides congenital long-QT syndrome. Circ Arrhythm Electrophysiol 5(4): 782-788.

7. Zipes DP, Camm AJ, Borggrefe M, Buxton AE, Chaitman B, et al. (2006) ACC/AHA/ESC 2006 guidelines for management of patients with ventricular arrhythmias and the prevention of sudden cardiac death: a report of the American College of Cardiology/American Heart Association Task Force and the European Society of Cardiology Committee for practice guidelines (writing committee to develop guidelines for management of patients with ventricular arrhythmias and the prevention of sudden cardiac death): developed in collaboration with the European Heart Rhythm Association and the Heart Rhythm Society. Circulation 114(10): e385-e484.

8. Bardy GH, Lee KL, Mark DB, Poole JE, Packer DL, et al. (2005) Amiodarone or an implantable cardioverter-defibrillator for congestive heart failure. N Engl J Med 352(3): 225-237.

9. Hallstrom AP, Greene HL, Wyse DG, Zipes D, Epstein AE, et al. (1995) Antiarrhythmics versus implantable defibrillators (AVID)--rationale, design, and methods. Am J Cardiol 75(7): 470-475.

10. Hofferberth SC, Cecchin F, Loberman D, Fynn-thompson F (2014) Left thoracoscopic sympathectomy for cardiac denervation in patients with life-threatening ventricular arrhythmias. J Thorac Cardiovasc Surg 147(1): 404-409.

11. Bourke T, Vaseghi M, Michowitz Y, Sankhla V, Shah M, et al. (2010) Neuraxial modulation for refractory ventricular arrhythmias: value of thoracic epidural anesthesia and surgical left cardiac sympathetic denervation. Circulation 121(21): 2255-2262.

12. Cerfolio RJ, De campos JR, Bryant AS, Connery CP, Miller DL, et al. (2011) The society of thoracic surgeons expert consensus for the surgical treatment of hyperhidrosis. Ann Thorac Surg 91(5): 16421648.

13. Ajijola OA, Lellouche N, Bourke T, Tung R, Ahn S, et al. (2012) Bilateral cardiac sympathetic denervation for the management of electrical storm. J Am Coll Cardiol 59(1): 91-92.

14. Schwartz PJ (2014) Cardiac sympathetic denervation to prevent lifethreatening arrhythmias. Nat Rev Cardiol 11(6): 346-353. 
15. Vaseghi M, Barwad P, Malavassicorrales FJ, Tandri H, Mathuria N, et al. (2017) Cardiac sympathetic denervation for refractory ventricular arrhythmias. J Am CollCardiol 69(25): 3070-3080.

16. Estes EH, Izlar HL (1961) Recurrent ventricular tachycardia. A case successfully treated by bilateral cardiac sympathectomy. Am J Med 31(3): 493-497.

17. Zipes DP, Festoff B, Schaal SF, Cox C, Sealy WC, et al. (1968) Treatment of ventricular arrhythmia by permanent atrial pacemaker and cardiac sympathectomy. Ann Intern Med 68(3): 591-597.
18. LyraRde M, Campos JR, Kang DW, Loureiro Mde P, Furian MB, et al. (2008) Guidelines for the prevention, diagnosis and treatment of compensatory hyperhidrosis. J Bras Pneumol 34(11): 967-977.

19. Moraites E, Vaughn OA, Hill S (2014) Endoscopic thoracic sympathectomy. Dermatol Clin 32(4): 541-548.

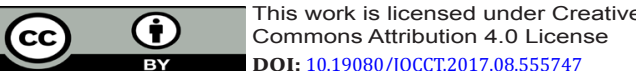

\section{Your next submission with Juniper Publishers} will reach you the below assets

- Quality Editorial service

- Swift Peer Review

- Reprints availability

- E-prints Service

- Manuscript Podcast for convenient understanding

- Global attainment for your research

- Manuscript accessibility in different formats

( Pdf, E-pub, Full Text, Audio)

- Unceasing customer service

Track the below URL for one-step submission https://juniperpublishers.com/online-submission.php 